\title{
Impact of Land Use Changes on Soil Properties and Organic Carbon Distribution Using Tracer Techniques in Selangor State of Malaysia
}

\author{
M.B. Hossain ${ }^{1 *}$, K. Jusoh ${ }^{2}$ and S. Fatimah ${ }^{2}$ \\ ${ }^{1}$ Soil Science Division, Bangladesh Institute of Nuclear Agriculture (BINA), BAU campus, \\ Mymensingh, Bangladesh \\ ${ }^{2}$ School of Environmental and Natural Resource Sciences, Faculty of Science and Technology, University \\ Kebangsaan Malaysia, Bangi, Selangor, Malaysia
}

Date Received:21-09-2017 Date Accepted: 23-12-2017

\begin{abstract}
Root and litter biomass on carbon dynamics and its effect on other soil properties information are needed to explore in Malaysia due to rapid change of land use.Objective of this study was to determine the effect of root and litter biomass of forest and oil palmunder different soil depths on soil organic carbon and its stock,soil available water, bulk density, $\mathrm{pH}$, electrical conductivity. In this regard, twoland use systems (forest and oil palm) were selected for the study. In each land use we collected litter biomass, root and soil samples from four different locations. For the characterization of soil and root three core samples were taken $(0-5,5-15,15-30,30-60$ and 60-90 cm)from each location, and then combined and air-dried.Soil samples were air-dried for 2 weeks at room temperature, grounded and sieved $(<2 \mathrm{~mm})$. Soil available water content, soil organic carbon, $\mathrm{pH}$ and $\mathrm{EC}$ were determined by standard methods.Results revealed that maximum organic matter $(6.75 \%)$ was found in forest soil at $0-5 \mathrm{~cm}$ depth of soil. SOC content was decreased with the increase of soil depth in forest. On average soil organic carbon stock was significantly higher under oil palm $\left(3.09 \mathrm{t} \mathrm{ha}^{-1}\right)$ than forest $\left(2.28 \mathrm{t} \mathrm{ha} \mathrm{h}^{-1}\right)$ up to $90 \mathrm{~cm}$ depth of soil. Available water content was higher in surface soil $(0-15 \mathrm{~cm})$ than subsurface soil due to mechanization of oil palm plantation area. Soil reaction $(\mathrm{pH})$ was higher in forest soil than oil palm plantation soil.Litter biomass or droppings performed $\delta^{13} \mathrm{C}$ dilution in surface soilbut root system enriched $\delta^{13} \mathrm{C}$ in subsurface soil. ${ }^{13} \mathrm{C}$ isotope tracer technique confirmed that root and litter biomass of forest and oil palm plantation can greatly influence on vertical distribution of organic carbon when soils show gradual increase of $\delta^{13} \mathrm{C}$ values with depth.
\end{abstract}

Keywords: Land use,forest and oil palm, soil depth,carbon,tracer techniques

\section{Introduction}

Land-use changes in tropical ecosystem lead to major modifications of soil properties and processes. In 2012 Malaysia had 5.08 million hectares of oil palm plantation. Over the year's oil palm plantation keep increasing since 2008 by $11.8 \%$ and contributed $39 \%$ of the world's total palm oil production (Board, 2012). A rapid change of land use from natural forest to plantation agriculture inMalaysia is increased due to attain sufficiency for food, oil, and biofuels (Fargione et al., 2008; Gibbs et al., 2008; Kurniawan, 2016). Specially land use affects SOC stock, $\mathrm{CO}_{2}$ exchange and soil physicalchemical properties.Several investigators have reported a net loss of SOC (Kotowska et al., 2015).

Conversely, others had reported that the conversion to oil palm plantations led to a net gain of soil C stock (Flynn et al., 2012; Frazao et al., 2013; Patthanaissaranukool and Polprasert, 2011; Siangjaeo et al., 2011).Land use changes can perform a great variation on litter biomassto soil surface and plant root 
density in soil(Laganiere et al., 2010). In accordance with the knowledge of authors, information about the effect of biomass distribution and root systemsin forest and oil palm plantation on carbon distribution and other soil propertiesis generally scarce in Selangor State of Malaysia.Plant functional types significantly affected the vertical distribution of SOC.Carbon isotope tracer technique was also used to confirm the source of carbon stored in forest and oil palm soils because decomposition of SOC directly effects its isotopic composition. The present investigation was planned to examine the effect of litter biomass and plant roots of forest and oil palm plants on vertical distribution and source of soil organic carbon using ${ }^{13} \mathrm{C}$ tracer technique and also to evaluate the impact of land use changes in soil available water, bulk density, $\mathrm{pH}$ and electrical conductivity.

\section{Materials and Methods}

\subsection{Study site}

Two land uses namely tropical forest and oil palm plantation located at Bangi in Selangor State, Malaysia were selected for the study (Figure 1).Oil palm plantationis of 37 years old at University Putra Malaysia (UPM).
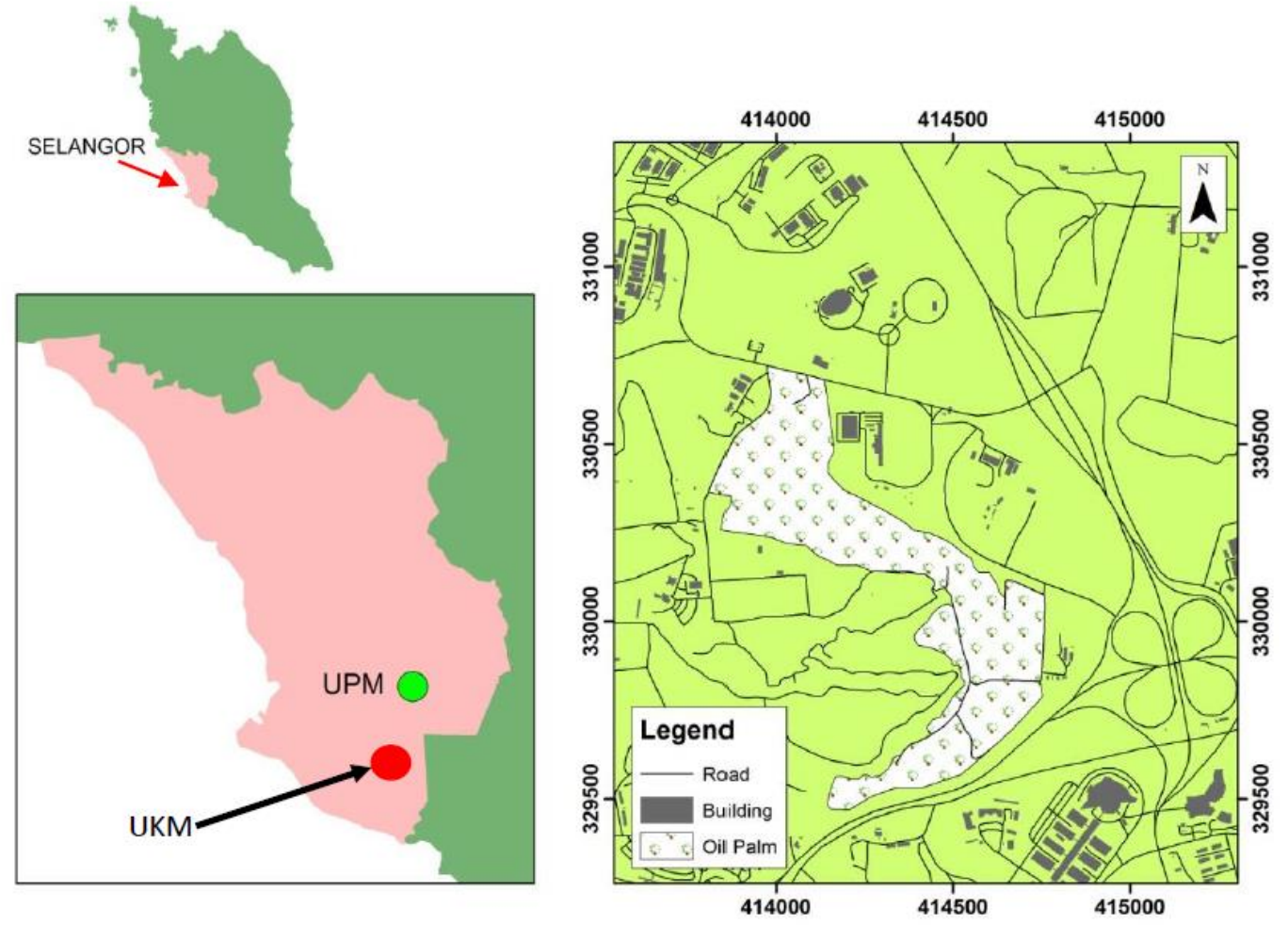

Figure 1:Map showing the locations of the study areas (forest area:University Kebangsaan Malaysia (UKM), oil palm area: University Putra Malaysia (UPM) in Selangor State of Malaysia.

The University Kebangsaan Malaysia (UKM) Permanent Forest Reserve is an area within the main campus of UKM in Bangi, developed in an area formerly known as Bangi Forest Reserve (BFR).The Bangi Forest Reserve (BFR) lies between $2^{\circ} 54^{\prime}$ and $101^{\circ} 4.5^{\prime} \mathrm{E}$ in the district of Rulu Langat, Selangor Darul Ehsan, some $35 \mathrm{~km}$ south of Kuala Lumpur.This quartzite soft rock-based forest is bordered by the Langat river in the North and Kuala Lumpur-Seremban highway in the South. Topographically the area is moderately flat with several small streams and patches of swamps, at altitude of $40 \mathrm{~m}$ to $110 \mathrm{~m}$ above sea level. 


\subsection{Sampling and analysis}

Experiment was carried out from June to December; 2016.Two land use systems (forest and oil palm) were selected for the study.
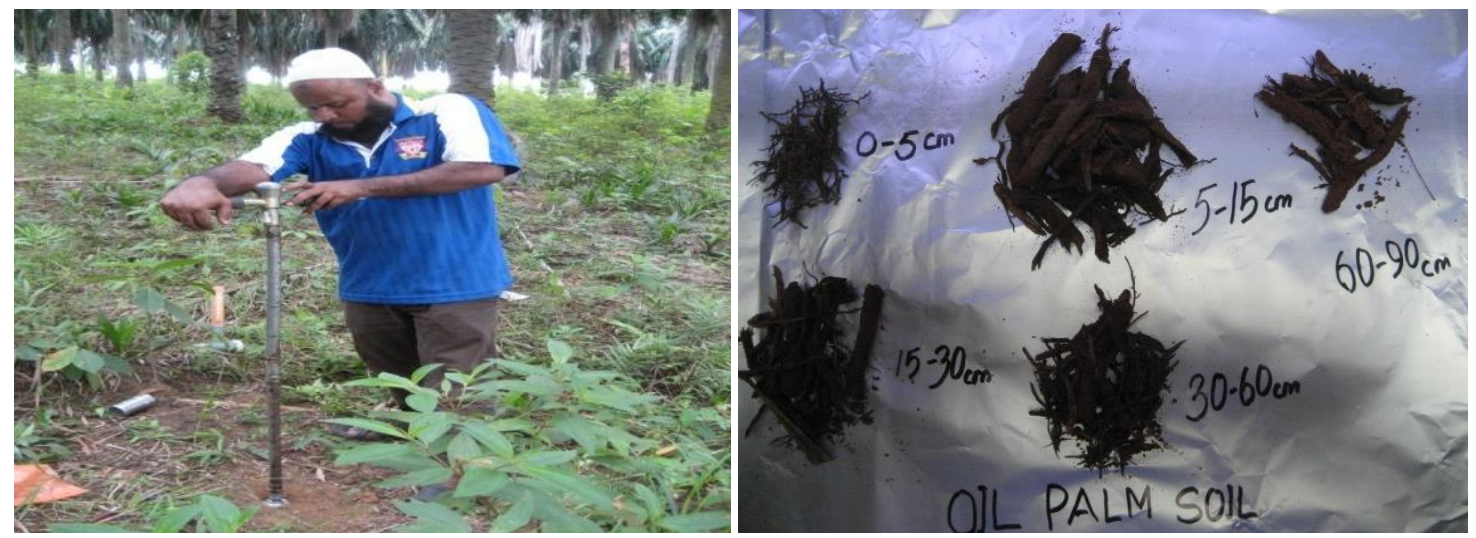

Figure2: Oil palm root at different depths of soil.

In each land use we collected litter biomass, root and soil samples from four different locations. For the characterization of soil and root three core samples were taken $(0-5,5-15,15-30,30-60$ and 60$90 \mathrm{~cm}$ ) from each location (Figure 2). Three soil core samples from each depth were mixed in homogenously to make composite sample.Then the samples were dried, grinded and sieved with a $<2.0 \mathrm{mmsieve}$ and stored. Litter biomass was collected from $1.0 \mathrm{~m}^{2}$ area and it converted in $\mathrm{g} / 0.10 \mathrm{~m}^{2}$. Amount of root was estimated from different soil profiles in respect of their depth. Depth-wise soil sampleswere collected using a metal core sampler for bulk density analysis (Blake and Hartage, 1986). Soil pH (soil:water 1:2.5) and electrical conductivity (EC) was determined by following standard methods (Jackson, 1967).Available water contents were determined using ceramic plates (Townend et al., 2001).

\subsection{Soil organic carbon stock calculation}

Organic carbon stock results were estimated using the total forest and oil palm plantation areas (18,270,000 and 222,778 ha) (MSPO, 2015; NRE, 2016), respectively. The size of the total C stock is calculated following the method as described by Batjes (1996). It involves calculation of soil organic carbon (SOC) bymultiplying the proportion of organic carbon in a given site by bulk density and the thickness of the horizon for individual soil sample with different thicknesses varying from $0-5,5-15,15$ $30,30-60$ and $60-90 \mathrm{~cm}$. The total SOC stock was calculated using this formula.

SOC stock in soil $=\mathrm{BD} \times \mathrm{C}_{\mathrm{org}} \times \mathrm{D} \times \mathrm{A}$

Where:

$\mathrm{BD}=$ Bulk density of soil $\left(\mathrm{g} \mathrm{cm}^{-3}\right)$

$\mathrm{C}_{\text {org }}=$ Mass concentration of organic carbon $(\%)$ in soil

$\mathrm{D}=$ Depth of soil $(\mathrm{cm})$

$\mathrm{A}=$ Area of land covered by forest and oil palm and lastly SOCstock converted in $\mathrm{tha} \mathrm{ha}^{-1}$.

Isotopic composition is expressed in $\delta$ notation (in \%)

$\mathrm{R}_{\text {sample }}$ 
$\delta(\%)=[-----------------~-1] \times 1000$

$\mathrm{R}_{\text {standard }}$

Where:

$\mathrm{R}=$ Molar ratio of heavy to light isotope of the sample or the international PDB reference.

Accordingly, ${ }^{13} \mathrm{C}$ enrichment leads to less negative $\delta^{13} \mathrm{C}$ values. In natural systems, kinetic fractionation leads to a substrate ${ }^{13} \mathrm{C}$ enrichment.Appropriate statistical analyses were performed with the mean data of each parameter. Mean differences of different parameters were tested by analysis of variance (Gomez and Gomez, 1984; Table 1) except litter biomass and its organic carbon content. Standard deviation was used for litter biomass and its organic carbon.

\section{Results}

To determine the contribution of plant roots and litter biomass onsoil organic carbon (SOC), we analysed the mean root dry weight and litter biomass fresh and dry weight values up to $90 \mathrm{~cm}$ i.e. five depths of soil profile (Figure3a,b \& c).
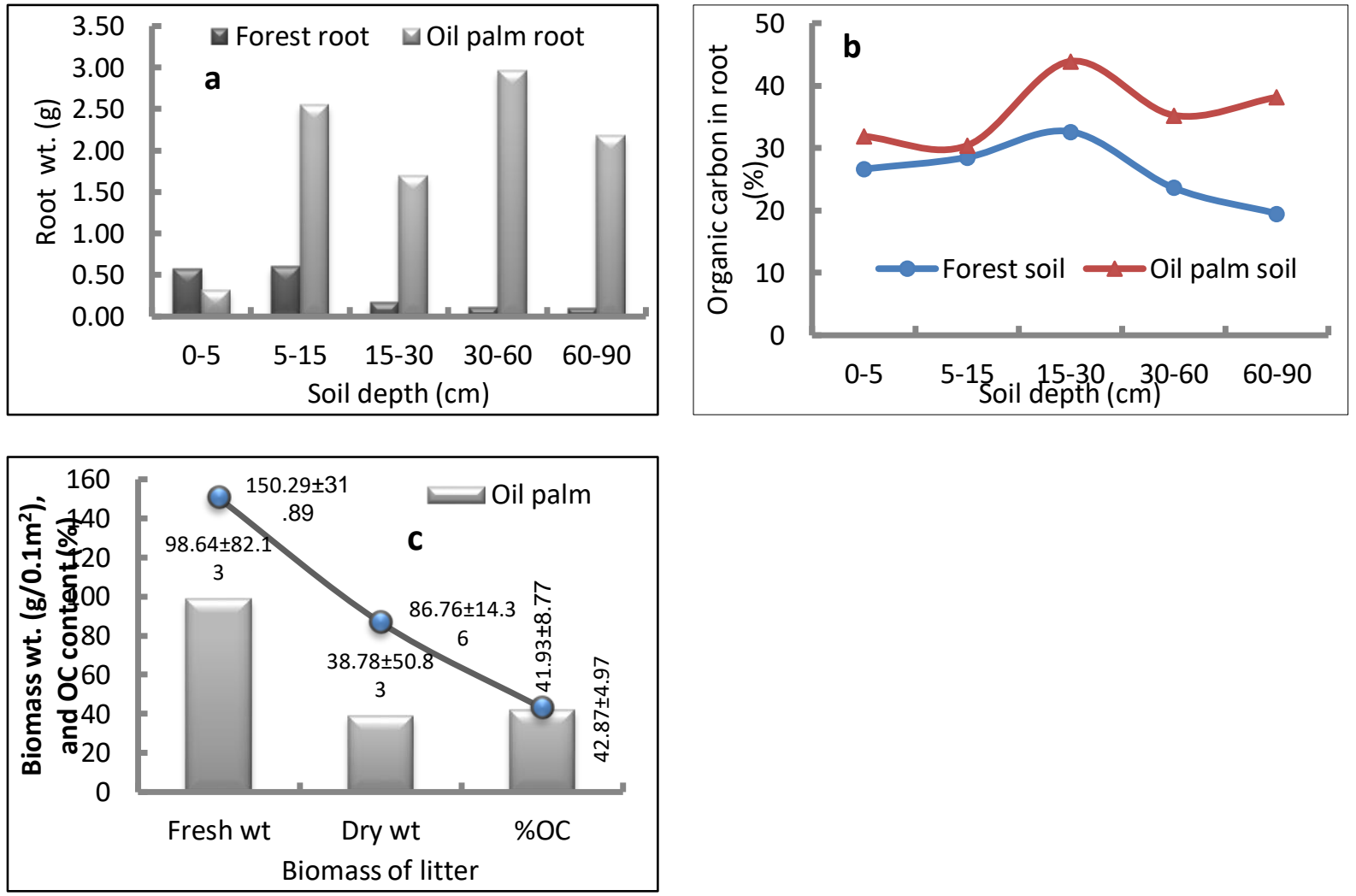

Figure3: Mean root dry weight (a), root organic carbon at different land use with soil depth and fresh, dry weight of biomass of litter and organic carbon content (c) on surface soil.

The mean root dry weight value (mean value of five soil depth profile) was higher under oil palm plantation $(1.94 \mathrm{~g})$ than under forest $(0.31 \mathrm{~g})$ except $0-5 \mathrm{~cm}$ depth of soil (Figure $3 \mathrm{a})$. Maximum root dry 
weight was obtained from 30-60 $\mathrm{cm}$ soil depth and the minimum root dry weight was found in $60-90 \mathrm{~cm}$ depth of soil in forest area. Root organic carbon content results are presented (Figure3b).Higher root organic carbon was found in oil palm plantation soil than forest soil. Maximum organic carbon content was observed in 5-15 cm depth of soil both in oil palm and forest soil. Litter biomass as well as organic carbon content results are presented (Figure3c).Maximum fresh and dry weights of surface residue were obtained from forest area and minimum fresh and dry weights of residue were found in oil palm plantation area. Little bit higher organic carbon was found in forest residue. More or less similar trend organic carbon content was observed in forest and oil palm plantation. The effects of soil depth and land use on organic matter and its stock, available water, bulk density, $\mathrm{pH}$ and EC results are presented (Figure4a, b, c, d, e \& f).
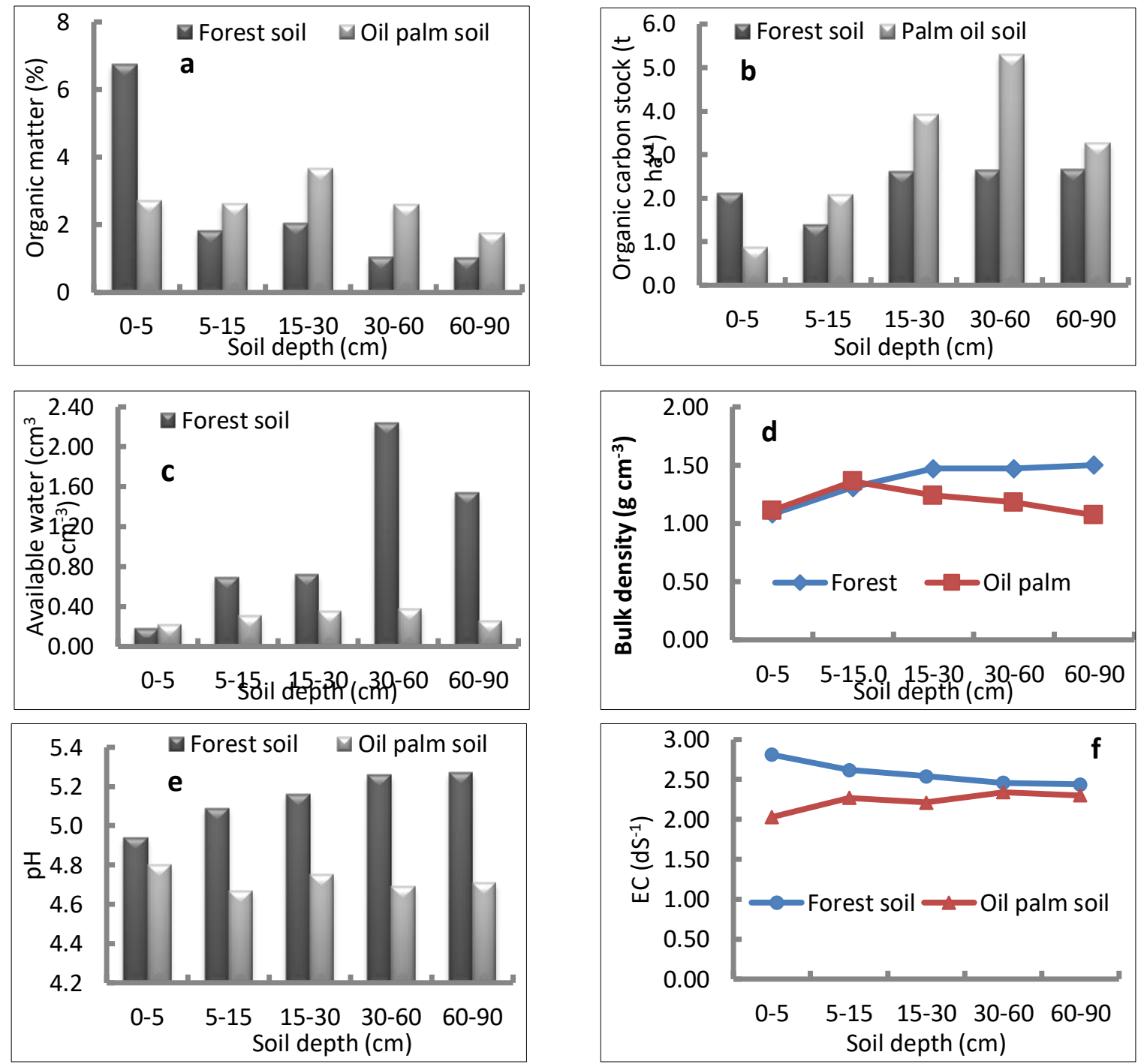

Figure4: Mean soil organic matter (a), soil carbon stock (b), available water (c), bulk density (d), pH (e) and EC (f) at different land use with soil depth.

Organic matter in forest soils was higher at 0-5 cm depth than oil palm soil (Figure 4a). In forest soil, organic matter decreased with the increase of soil depth except $15-30 \mathrm{~cm}$ depth. Maximum soil organic matter $(6.75 \%)$ was found in forest soil at $0-5 \mathrm{~cm}$ depth. Inconsistent results of organic matter were found in oil palm plantation soil. Maximum organic matter was found in $15-30 \mathrm{~cm}$ depth of oil palm soil. On average, organic matter increased $(5 \%)$ in oil palm plantation over forest soil.Organic carbon 
stock, significant variation was found in different land use with soil depth (Figure 4b). Maximum organic carbon stock was found in 30-60 cm depth in oil palm soil. Organic carbon stock was higher in oil palm soil than forest soil in different depth of soil except $0-5 \mathrm{~cm}$ depth.Available water content results in forest and oil palm soil are presented (Figure4c).Higher available water was also observed at lower soil depths in forest area.On the other hand, higher available water contain was found in $0-15 \mathrm{~cm}$ depthin oil palm soil but there after it was decreased up to $90 \mathrm{~cm}$ soil depth. Soil bulk density (BD) results for the two land use types at different soil depths are shown in Figure 4d. BD in forest soils was lower at 0-5 and 5-15 cm depths than oil palm soil and the latter depths BD were higherin forest soil than oil palm soil.Soil BD was decreased with the increase of soil depth in oil palm plantation but the opposite results were found in forest soil. Figure4e shows the results of soil $\mathrm{pH}$ for forest and oil palm plantation.There were significant differences in forest and oil palm plantation systems. Soil $\mathrm{pH}$ for oil palm plantation was significantly lower than for forest soil. The $\mathrm{pH}$ value increased with the increase in different depths of forest soil but the inconsistent results were found in oil palm plantation in respect of soil depth. The ranged of $\mathrm{pH}$ 4.945.27 in forest soil. Maximum $\mathrm{pH}$ (4.96) was found in 30-60 $\mathrm{cm}$ depth of oil palm soil.Therefore high $\mathrm{SOM}$ in soils lowers soil pH.Electrical conductivity (EC) results are shown (Figure4f).pH results increased with the decreased of electrical conductivity.

The $\delta^{13} \mathrm{C}$ distribution results with depth in soils of forest and oil palm plantation are presented (Figure5). The $\delta^{13} \mathrm{C}$ values in different depths of soil in forest were higher than oil palm plantation. The $\delta^{13} \mathrm{C}$ values, however, were similar in $5-15 \mathrm{~cm}$ depth of soil both forest and oil palm plantation.

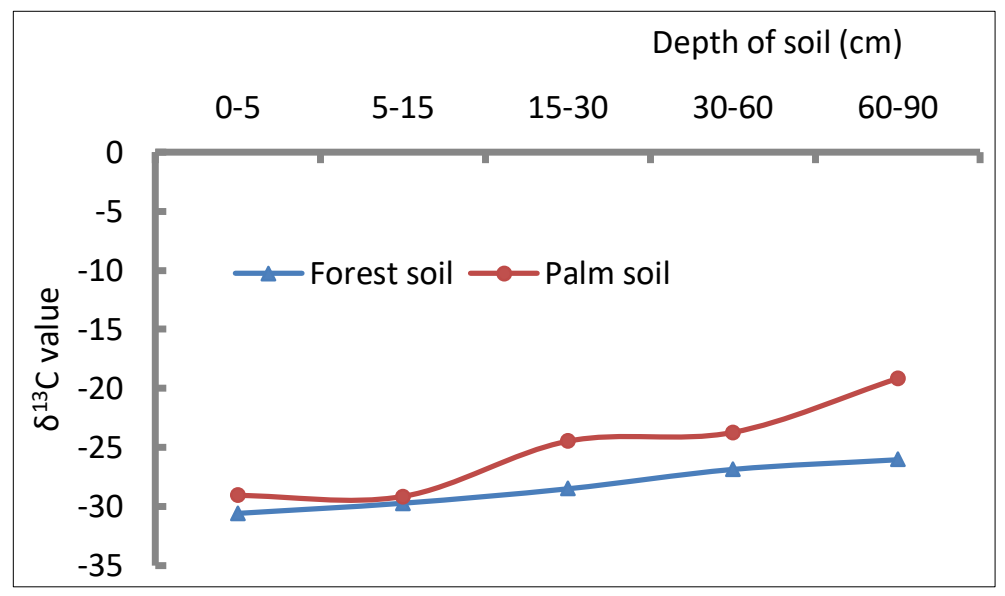

Figure 5: Impact of forest conversion by oil palm plantation on $\delta^{13} \mathrm{C}$ distributions in different land use with soil depth.

The lowest $\delta^{13} \mathrm{C}$ distribution value was found in $60-90 \mathrm{~cm}$ depth of soil. $\delta^{13} \mathrm{C}$ distribution values were more or less similar trend in oil palm plantation soil. At $60-90 \mathrm{~cm}$ soil depth, $\delta^{13} \mathrm{C}$ values were higher in forest soil than oil palm plantation soil. Oil palm plantation soil contained more root biomass than forest biomass. Mean square of soil and vegetation of different land use systems are presented (Table 1).

Table 1:Mean square of soil properties and vegetation in different land uses of Malaysia.

\begin{tabular}{|c|c|c|c|c|c|c|c|c|}
\hline \multirow{2}{*}{\multicolumn{2}{|c|}{$\begin{array}{l}\text { Source of } \\
\text { variation }\end{array}$}} & Organi & matter & $\begin{array}{l}\text { Organic carbon } \\
\text { in residues }\end{array}$ & $\mathrm{pH}$ & & $\mathrm{EC}$ & \\
\hline & & Forest & Palm & Forest $\quad$ Palm & Forest & Palm & Fores & Palm \\
\hline
\end{tabular}




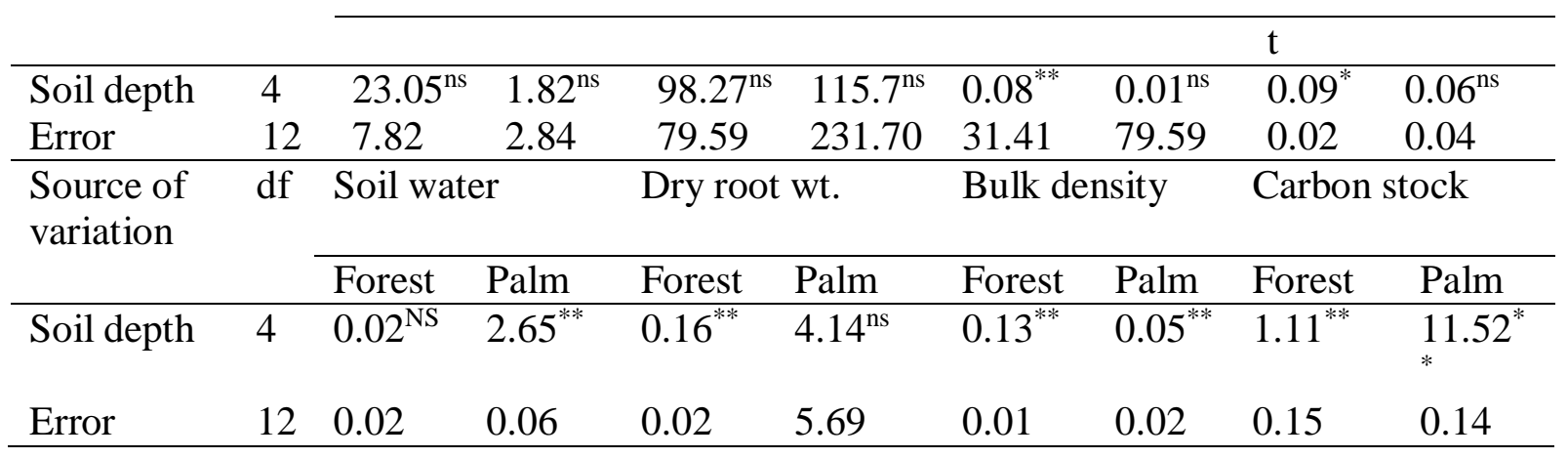

\section{Discussion}

\subsection{Soil organic matter}

Maximum organic matter $(6.75 \%)$ was found in forest soil at $0-5 \mathrm{~cm}$ depth. This is because the litter biomass of forest land is not removed by man and animal those contribute organic carbon from their droppings. Maximum organic matter was found in 15-30 cm depth of oil palm soil. On average, organic matter increased $(5 \%)$ in oil palm plantation over forest soil. This can be due to higher amount of root as well as organic carbon content in oil palm soil. The contribution of root inputs to organic $\mathrm{C}$ can greatly influence both the total amount and vertical distribution of SOC in different depth of soil (Oelbermann and Voroney, 2007; Rumpel and Kogel-Knabner, 2011).Similar findings were reported by Keen et al. (2011). Conversion to oil palm plantation led to a net gain of soil C stock (Flynn et al., 2012; Frazao et al., 2013; Patthanaissaranukool and Polprasert, 2011; Siangjaeo et al., 2011) due to suitable land management systems (Adugna and Abegaz, 2016; Six et al. 2002). Land use change can lead to an alteration of the amounts and qualities of SOM (Coleman et al., 1989) and can potentially either release or sequester soil carbon (Mendham et al., 2003). Rasse et al. (2005) also reported that the incorporation of C into the soil was much greater due to plant roots than due to aboveground litter. This information are strongly supported to our findings.

\subsection{Soil bulk density, $p H$ and $E C$}

Higher soil bulk densities in the forest soil may have enhanced the soil's ability to retain water. Higher soil bulk densities were found in $5-15 \mathrm{~cm}$ depth of soil due to mechanization in oil palm plantation soil. These phenomena may hinder the permeability of water from surface soil to subsurface soil. Yahya et al. (2010) reported that the effect of mechanization increased the bulk density of oil palm plantation soil. They also reported that soil BD was affected by the compaction only within the first $0-10 \mathrm{~cm}$ depth and there after it was not affected by the mechanization. This information on the effect of land use changes are supported to our research findings. Intercultural operations and fertilizer management performed the decline of soil $\mathrm{pH}$ in oil palm area. Organic and inorganic acids are formed from the decomposed SOM. These can reduce the soil $\mathrm{pH}$ due to soil organic matter (SOM) is low in base forming cations (Brady and Weil, 1996). EC value was higher in forest soil than oil palm soil in respect of soil depth. Highest and lowest EC values were found at $0-5 \mathrm{~cm}$ soil depth both in forest oil palm soil, respectively. At $60-90 \mathrm{~cm}$ soil depth EC value was more or less similar to forest and oil palm soil.

\section{$4.3 \delta^{13} \mathrm{C}$ distribution in different depths of soil}

Maximum negative $\delta^{13} \mathrm{C}$ value was obtained from 0-5 depth of soil in forest area due to higher biomass on top soil which was controlled by local environmental condition. Negative $\delta^{13} \mathrm{C}$ value decreased with the increase of soil depth in forest and oil palm soil. Decomposition of droppings performed $\delta^{13} \mathrm{C}$ dilution in surface soil. Werth and Kuzyakov (2010) also reported that top soils $\delta^{13} \mathrm{C}$ 
values distribution were higher than subsoil because root-to-shoot ratio increases with soil depth, which might enrich SOC with $1.2 \% \delta^{13} \mathrm{C}$ by root. As a result, more advanced decomposition in older SOC, physical mixing favors the migration of smaller and more strongly decomposed SOC particles down the soil profile. This leads to a higher proportion of older and more decomposed SOC in deeper horizons. Similar results were found by Trumbore (2000).

\section{Conclusions}

Land use significantly affected litter and root biomass, soil $\mathrm{pH}, \mathrm{EC}$, organic carbon, available water content in soil. Soil organic carbon decreased with the increase of soil depth. The highest organic carbon content was found at $0-5 \mathrm{~cm}$ depth of forest soil. Root biomass as well as lower SOC mineralizationcontributed less negative $\delta^{13} \mathrm{C}$ value in subsurface soil.

On the other hand, surface soil was more negative $\delta^{13}$ Cvalue due to incorporation of litter biomass. Sub-surface SOC was lower than surface soil in forest soil. This could be caused by reduced incorporation of SOC into smaller fractions in lower depth of soil. Carbon isotope $\left(\delta^{13} \mathrm{C}\right)$ tracer technique proved that the soil organic carbon dynamics were showed different patterns in different depth of soil due to mineralization of SOC, litter biomass and root systems. So, $\delta^{13} \mathrm{C}$ depth profiles may be a powerful tool to determine the source of organic carbon and to estimate the degree of SOC mineralization after conversion of natural forest tooil palm plantation.

\section{Acknowledgements}

The authors would like to thank the Ministry of Agriculture, People's Republic of Bangladesh and Bangladesh Institute of Nuclear Agriculture for financial support. Authors also thank to the School of

Natural and Environmental Resource Sciences, University Kebangsaan Malaysia, Malaysia for providing the Laboratory facility.

\section{References}

Adugna, A., Abegaz,A. 2016. Effects of land use changes on the dynamics of selected soil properties in northeast Wellega, Ethiopia. Soil, 2(1): 63-70.

Batjes, N.H. 1996. Total carbon and nitrogen in the soils of the world. Eurasian Journal of Soil Science, 47: 151-163.

Blake, G.R.,Hartage,K.H. 1986. Bulk density. In: Klute, A. (Ed.), Method of soil analysis,Part I, 2 nd ed. Physical and Mineralogical Methods: Agronomy Monograph no.9,pp. 363-375.

Board, M.P.O. 2012. Overview of the Malaysian oil palm industry 2011: Selangor: Economics \& Industry Development Division

Brady, N.C.,Weil,R.R.1996. The Nature and Properties of Soils. Prentice Hall, pp. 343-490.

Coleman, D.C., Oades, J.M. Vehara, G. 1989. Dynamics of soil organic matter in Tropical ecosystems. NifTAL Project, pp. 5-32. Soil and Plant Analysis Council, inc. (2000). Soil analysis handbook of reference methods, pp. 33-35.

Fargione, J., Hill,J.,Tilman, D., Polasky, S.,Hawthorne,P. 2008. Land Clearing and the Biofuel Carbon Debt. Science, 319(5867): 1235-1238.

Flynn, H.C., Keller,E.,King, H., Sim, S.,Hastings,A.,Wang, S.,Smith,P. 2012. Quantifying global greenhouse gas emissions from land-use change for crop production. Global Change Biology, 18(5): 1622-1635.

Frazao, L.A., Paustian, K., Pellegrino Cerri, C.E. Cerri,C.C. 2013. Soil carbon stocks and changes after oil palm introduction in the Brazilian Amazon. GCB Bioenergy, 5(4): 384-390. 
Gibbs, H.K., Johnston, M., Foley,J.A., Holloway, T., Monfreda, C., Ramankutty, N. Zaks,D.2008. Carbon payback times for crop-based biofuel expansion in the tropics: the effects of changing yield and technology. Environmental Research Letter, 3(3): 034001.

Kotowska, M.M., Leuschner,C., Triadiati, T.,Meriem, S., Hertel,D. 2015. Quantifying above-and belowground biomass carbon loss with forest conversion in tropical lowlands of Sumatra (Indonesia). Global Change Biology, 21(10): 3620-3634.

Kurniawan, S. 2016. Conversion of lowland forests to rubber and oil palm plantations changes nutrient leaching and nutrient retention efficiency in highly weathered soils of Sumatra, Indonesia.

Gomez, K.A., Gomez,A.A. 19984. Statistical Procedure for Agricultural Research. $2^{\text {nd }}$ Edn. John \& WileySons, N.Y.,pp. 97-411.

Jackson, M.L. 1967. Soil Chemical Analysis. Prentice hall of India Pvt, New Delhi, India. pp. $205-226$.

Laganiere, J., Angers, D.A.,Pare,D. 2010. Carbon accumulation in agricultural soils after afforestation: a meta-analysis. Global Change Biology, 16: 439-53.

MSPO(Malaysian Sustainable Palm Oil). 2015. Malaysia sets timeline for MSPO certification compliance, Malaysian Palm Oil Certification Council (MPOCC) official website, http://www.mpocc.org.my/single-post/2017/02/25/Malaysia-sets-timeline-for-MSPOcertification-compliance

Mendham, D.S., O’Connell, A.M. Grove,T.S. 2003. Change in soil carbon after land clearing or afforestration in highly weathered lateritic and sandy soils of South- Western Australia. Agriculture Ecosystems Environment, 95: 143-156.

NRE(Natural Resources and Environment). 2016. Total forested area in Malaysia (1990-2014). Ministry of Natural Resources and Environment, Wisma Sumber Asli, No. 25 Persiaran Perdana, Presint 4, 62574 Putrajaya, Malaysia.

Oelbermann, M., Voroney,R.P. 2007. Carbon and nitrogen in a temperate agroforestry system: Using stable isotopes as a tool to understand soil dynamics. Ecological Engineering, 29: 342-349.

Patthanaissaranukool, W., Polprasert,C. 2011. Carbon mobilization in oil palm plantation and milling based on a carbon-balanced model-a case study in Thailand. Environment Asia, 4(2): 17-26.

Rasse, D.P., Rumpel,C.,Dignac,M.F. 2005. Is soil carbon mostly root carbon? Mechanisms for a specific stabilisation. Plant Soil, 269: 341-356.

Rumpel, C. and I. Kogel-Knabner, 2011. Deep soil organic matter - a key but poorly understood component of terrestrial C cycle. Plant Soil, 338.

Siangjaeo, S., S.H., Gheewala, K. U., Chidthaisong,A. 2011. Implications of land use change on the life cycle greenhouse gas emissions from palm biodiesel production in Thailand. Energy Sustainable Development, 15(1): 1-7.

Six, J., Feller, C.,Denef,K., Ogle,S., Sa, J.C.D.M.,lbrecht,A.A. 2002. Soil organic matter, biota and aggregation in temperate and tropical soils-effects of no-tillage. Agronomie, 22(7-8): 755-775.

Townend, J., Reeve,M.J.,Carter,A. 2001. Water release characteristics. Soil Environ. Anal. Phy. Meth. $2^{\text {nd }}$ Edn. Revised and Expanded, ISBN: 0824704142, pp: 111.

Trumbore, S. 2000. Age of soil organic matter and soil respiration: radiocarbon constraints on belowground C dynamics. Ecological Applications, 10: 399-411.

Werth, M., Kuzyakov,Y. 2010. ${ }^{13} \mathrm{C}$ fractionation at the root-microorganisms-soil interface: a review and outlook for partitioning studies. Soil Biology \&Biochemistry, 42: 1372-1384.

Yahya, Z., Husin,A.,Talib, J.,Othman, J.,Ahmad, O.H., Jalloh,M.B. 2010. Soil compaction and oil palm (Elaeis guineensis) yield in a clay textured soil. American Journal of Agricultural Biological Sciences,5(1): 15-19. 